Prepared in cooperation with the National Park Service, Glen Canyon National Recreation Area

\title{
Sediment and Water Chemistry of the San Juan River and Escalante River Deltas of Lake Powell, Utah, 2010-2011
}

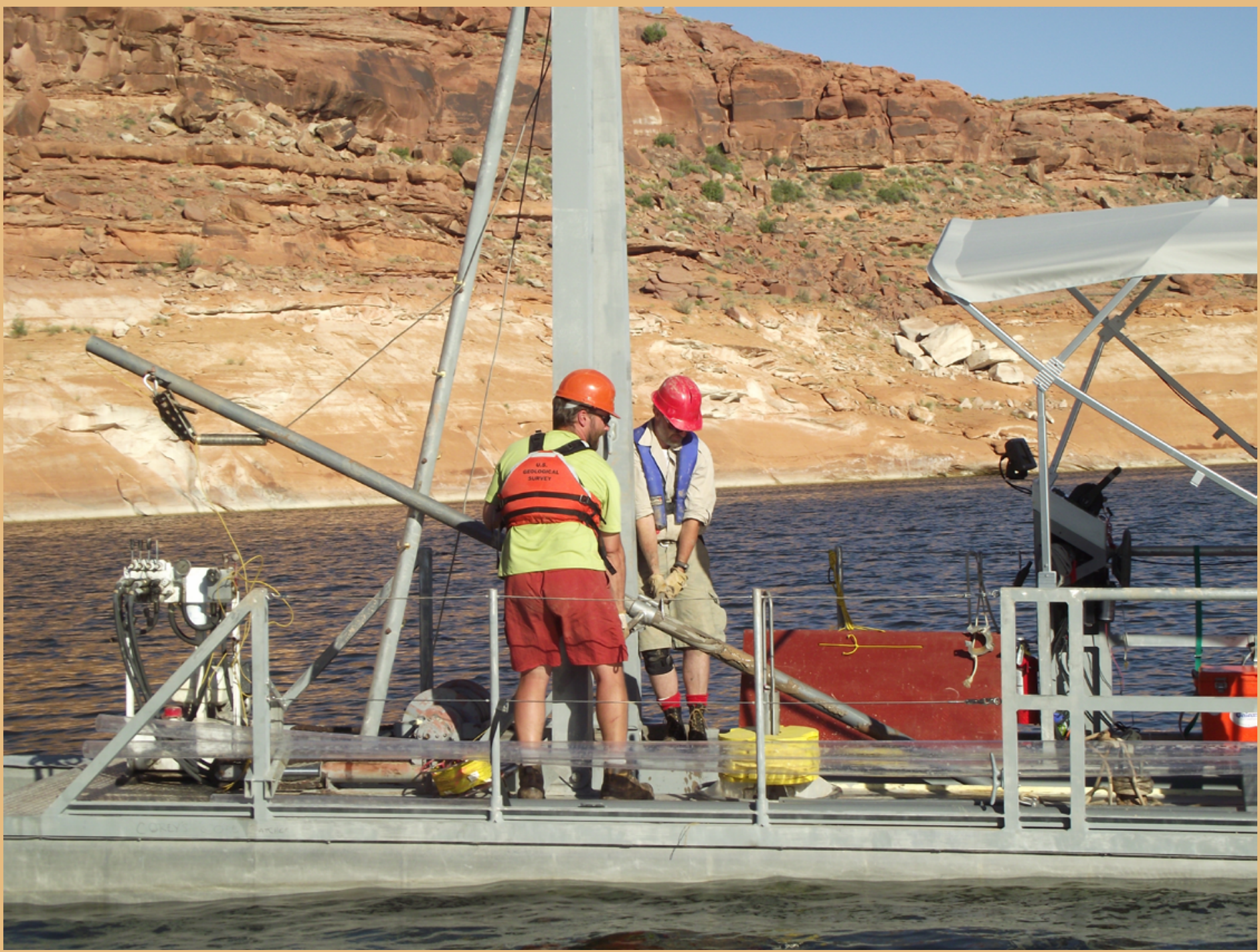

Open-File Report 2014-1096 
COVER

U.S. Geological Survey employees handling a sediment core on the San Juan River in Utah. Photograph by Robert J. Hart. 


\section{Sediment and Water Chemistry of the San Juan River and Escalante River Deltas of Lake Powell, Utah, 2010-2011}

By N.J. Hornewer

Prepared in cooperation with the National Park Service, Glen Canyon National Recreation Area

Open-File Report 2014-1096 


\title{
U.S. Department of the Interior SALLY JEWELL, Secretary
}

\section{U.S. Geological Survey Suzette M. Kimball, Acting Director}

\author{
U.S. Geological Survey, Reston, Virginia: 2014
}

For more information on the USGS - the Federal source for science about the Earth, its natural and living resources, natural hazards, and the environment-visit http://www.usgs.gov or call 1-888-ASK-USGS

For an overview of USGS information products, including maps, imagery, and publications, visit http://www.usgs.gov/pubprod

To order this and other USGS information products, visit http://store.usgs.gov

Any use of trade, firm, or product names is for descriptive purposes only and does not imply endorsement by the U.S. Government.

Although this information product, for the most part, is in the public domain, it also may contain copyrighted materials as noted in the text. Permission to reproduce copyrighted items must be secured from the copyright owner.

Suggested citation:

Hornewer, N.J., 2014, Sediment and water chemistry of the San Juan River and Escalante River deltas of Lake Powell, Utah, 2010-2011: U.S. Geological Survey Open-File Report 2014-1096, 7 p., http://dx.doi.org/10.3133/ofr20141096.

ISSN 2331-1258 (online) 


\section{Acknowledgments}

The author would like to thank Mark Anderson, aquatic ecologist, and Carolyn Hackbarth, hydrologic technician, from the National Park Service Glen Canyon National Recreation Area for their significant contribution and assistance with this study. In addition, thanks to Robert Hart from the U.S. Geological Survey Arizona Water Science Center (AzWSC) and Howard Taylor from the U.S. Geological Survey-Water Resources Discipline-National Research Program (NRP), Boulder, Colorado for developing and designing this study; Ronald Antweiler from NRP for his guidance and expertise with field-collection and analytical methods; David Roth from NRP and Corey Sannes from the AzWSC for their expertise with operating the coring rig; Kurt Schonauer from the AzWSC for his guidance; Greg Fisk from the AzWSC for his logistical expertise; Terry Plowman, chemist from NRP, for her contribution with sample processing and analyses; and William Vernieu, hydrologist from U.S. Geological Survey Grand Canyon Monitoring and Research Center, for his assistance with processing and providing bathymetric-survey information for the deltas. 


\section{Contents}

Abstract
Introduction.
Methods.
Summary of Core and Water Analyses
Appensideration for Future Studies
Results for the San Juan River delta, Lake Powell, Utah, 2010
Results for the Escalante River delta, Lake Powell, Utah, 2011.

\section{Figures}

1. Map showing location of study area and core sampling sites, San Juan River and Escalante River deltas, Lake Powell, southeastern Utah ....

2. Sediment-accumulation profiles and coring locations in the deltas of the San Juan River $(A)$ and Escalante River $(B)$ inflow reaches to Lake Powell, Utah, and sediment and lake elevations for 1986 through 2011

3. Logs showing cores, core sections and lengths, subsample locations, and composited samples collected from the San Juan River and Escalante River deltas, Lake Powell, Utah 


\section{Conversion Factors and Datums}

\begin{tabular}{lcl}
\hline \multicolumn{1}{c}{ Inch/Pound to SI } & By & \multicolumn{1}{c}{ To obtain } \\
\hline & Lultiply & \\
\hline millimeter $(\mathrm{mm})$ & 0.03937 & inch (in.) \\
meter $(\mathrm{m})$ & 3.281 & foot $(\mathrm{ft})$ \\
kilometer $(\mathrm{km})$ & 0.6214 & mile $(\mathrm{mi})$ \\
meter $(\mathrm{m})$ & 1.094 & yard $(\mathrm{yd})$ \\
\hline & Mass & \\
\hline gram $(\mathrm{g})$ & 0.03527 & ounce, avoirdupois $(\mathrm{oz})$ \\
kilogram $(\mathrm{kg})$ & 2.205 & pound avoirdupois $(\mathrm{lb})$ \\
\hline & Radioactivity & \\
\hline becquerel per liter $(\mathrm{Bq} / \mathrm{L})$ & 27.027 & picocurie per liter $(\mathrm{pCi} / \mathrm{L})$
\end{tabular}

Temperature in degrees Celsius $\left({ }^{\circ} \mathrm{C}\right)$ may be converted to degrees Fahrenheit $\left({ }^{\circ} \mathrm{F}\right)$ as follows: ${ }^{\circ} \mathrm{F}=\left(1.8 x^{\circ} \mathrm{C}\right)+32$

\section{Abbreviated Water-Quality Units}

Chemical concentration and water temperature are given only in metric units. Chemical concentration in water is given in milligrams per liter (mg/L), micrograms per liter $(\mu \mathrm{g} / \mathrm{L})$, or nanograms per liter (ng/L). Milligrams per liter is a unit expressing the solute mass (milligrams) per unit volume (liter) of water. One thousand micrograms per liter is equivalent to 1 milligram per liter. For concentrations less than 7,000 milligrams per liter, the numerical value is about the same as for concentration in parts per million. Specific conductance is given in microSiemens per centimeter at 25 degrees Celsius $\left(\mu \mathrm{S} / \mathrm{cm}\right.$ at $\left.25^{\circ} \mathrm{C}\right)$. Radioactivity is expressed in picocuries per liter $(\mathrm{pCi} / \mathrm{L})$ or picocuries per gram $(\mathrm{pCi} / \mathrm{g})$, which is the amount of radioactive decay producing 2.2 disintegrations per minute in a unit volume (liter) of water or mass (gram) of sediment. Chemical concentration in bottom sediment is given in grams per kilogram $(\mathrm{g} / \mathrm{kg})$, micrograms per gram $(\mu \mathrm{g} / \mathrm{g})$, milligrams per kilogram $(\mathrm{mg} / \mathrm{kg})$, or micrograms per kilogram $(\mu \mathrm{g} / \mathrm{kg})$. Grams per kilogram is equal to parts per thousand (ppt). Milligrams per kilogram and micrograms per gram are equal to parts per million (ppm). Micrograms per kilogram are equal to parts per billion (ppb).

\section{Datums}

Vertical coordinate information is referenced to the North American Vertical Datum of 1929 (NAVD 29).

Horizontal coordinate information is referenced to the North American Datum of 1983 (NAD 83).

Elevation, as used in this report, refers to distance above the vertical datum. 



\title{
Sediment and Water Chemistry of the San Juan River and Escalante River Deltas of Lake Powell, Utah, 2010-2011
}

\author{
By N.J. Hornewer
}

\section{Abstract}

Recent studies have documented the presence of trace elements, organic compounds including polycyclic aromatic hydrocarbons, and radionuclides in sediment from the Colorado River delta and from sediment in some side canyons in Lake Powell, Utah and Arizona. The fate of many of these contaminants is of significant concern to the resource managers of the National Park Service Glen Canyon National Recreation Area because of potential health impacts to humans and aquatic and terrestrial species. In 2010, the U.S. Geological Survey began a sediment-core sampling and analysis program in the San Juan River and Escalante River deltas in Lake Powell, Utah, to help the National Park Service further document the presence or absence of contaminants in deltaic sediment.

Three sediment cores were collected from the San Juan River delta in August 2010 and three sediment cores and an additional replicate core were collected from the Escalante River delta in September 2011. Sediment from the cores was subsampled and composited for analysis of major and trace elements. Fifty-five major and trace elements were analyzed in 116 subsamples and 7 composited samples for the San Juan River delta cores, and in 75 subsamples and 9 composited samples for the Escalante River delta cores. Six composited sediment samples from the San Juan River delta cores and eight from the Escalante River delta cores also were analyzed for 55 low-level organochlorine pesticides and polychlorinated biphenyls, 61 polycyclic aromatic hydrocarbon compounds, gross alpha and gross beta radionuclides, and sediment-particle size.

Additionally, water samples were collected from the sediment-water interface overlying each of the three cores collected from the San Juan River and Escalante River deltas. Each water sample was analyzed for 57 major and trace elements.

Most of the major and trace elements analyzed were detected at concentrations greater than reporting levels for the sediment-core subsamples and composited samples. Low-level organochlorine pesticides and polychlorinated biphenyls were not detected in any of the samples. Only one polycyclic aromatic hydrocarbon compound was detected at a concentration greater than the reporting level for one San Juan composited sample. Gross alpha and gross beta radionuclides were detected at concentrations greater than reporting levels for all samples. Most of the major and trace elements analyzed were detected at concentrations greater than reporting levels for water samples.

\section{Introduction}

Lake Powell, located in northeastern Arizona and southeastern Utah (fig. 1), is the second largest reservoir in the United States. The reservoir was created by the construction of Glen Canyon Dam, completed in March 1963, and impounds three major rivers: the Colorado, San Juan, and Escalante. Sediment transported by these rivers is primarily deposited as deltas in the inflow reaches to Lake Powell. Deltas formed by the Colorado, San Juan, and Escalante Rivers are active areas of sediment deposition and erosion and change over time. They are affected by hydrology, regional climate, reservoir operations, and fluctuating lake levels (Ferrari, 1988; Pratson and others, 2008).

Deltas are potential sinks for contaminants introduced through natural processes and human activities, which may sorb to sediment and sink in deposition areas. When deltaic sediment is reworked and transported farther into the lake, contaminants can be released into the water and become bioavailable and potentially harmful to humans and aquatic and terrestrial species, and may affect water quality in downstream portions of the reservoir (Hart and others, 2005; Potter and Drake, 1989; Vernieu, 1997). Sediment cores collected from the Colorado River delta as part of a U.S. Geological Survey (USGS) study done in 2001 documented the presence of trace elements, organic compounds including polycyclic aromatic hydrocarbons (PAHs), and radionuclides in the sediment (Hart and others, 2004, 2005).

Glen Canyon National Recreation Area (Glen Canyon

NRA) resource managers are concerned about these contaminants and their potential effects on humans and the environment. In 2010, the USGS began another study, supported by the USGS Office of Water Quality's WaterQuality Assessment and Monitoring program and Glen Canyon NRA, to help Glen Canyon NRA resource managers document the presence or absence of these contaminants in deltaic sediment from the two other major tributaries to Lake Powell, the San Juan and Escalante Rivers. 


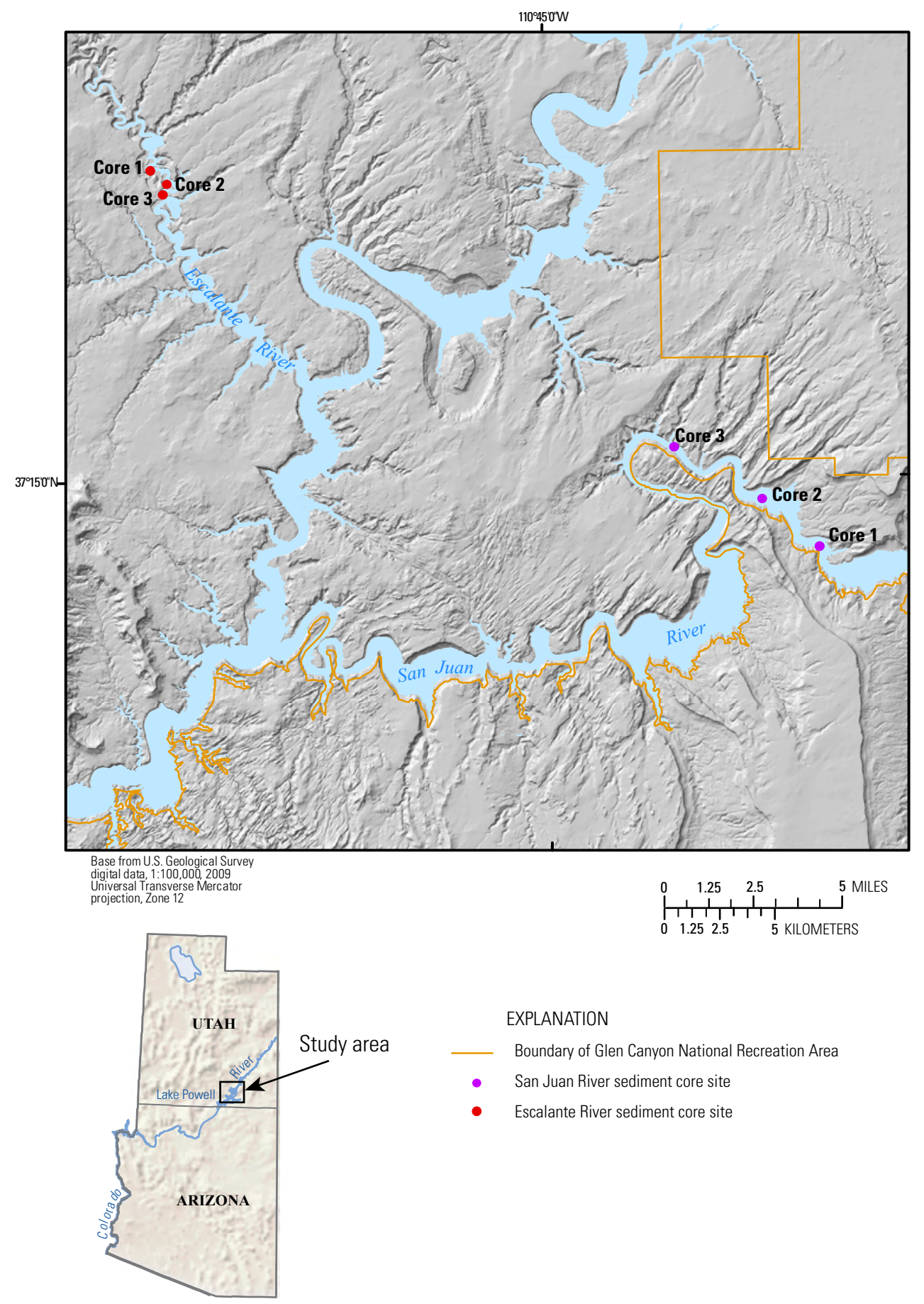

Figure 1. Map showing location of study area and core sampling sites, San Juan River and Escalante River deltas, Lake Powell, southeastern Utah.

The mouth of the San Juan River is approximately $100 \mathrm{~km}$ upstream of Glen Canyon Dam. In 1986, in the reach of the river where the sediment cores were collected (54-65 km upstream of the mouth), approximately $15 \mathrm{~m}$ of sediment had been deposited since the construction of Glen Canyon Dam (fig. 2A; appendix A1; Ferrari, 1988). Between 1986 and 2011, an additional $12 \mathrm{~m}$ of sediment was deposited (William Vernieu, Grand Canyon Monitoring and Research
Center, written commun., October 12, 2012). The mouth of the Escalante River is approximately $117 \mathrm{~km}$ upstream of Glen Canyon Dam. By 1986, approximately $13 \mathrm{~m}$ of sediment had been deposited in the river reach where the sediment cores were collected (27-30 km upstream of the mouth) and by 2011, an additional $9 \mathrm{~m}$ was deposited (fig. $2 B$; appendix B1; Ferrari, 1988; William Vernieu, Grand Canyon Monitoring and Research Center, written commun., October 12, 2012). 
Figure 2. Sedimentaccumulation profiles and coring locations in the deltas of the San Juan River (A) and Escalante River $(B)$ inflow reaches to Lake Powell, Utah, and sediment and lake elevations for 1986 through 2011. Data from Ferrari, 1988; Vernieu, Grand Canyon Monitoring and Research Center, written commun., October 12, 2012. Vertical datum is NGVD 29.

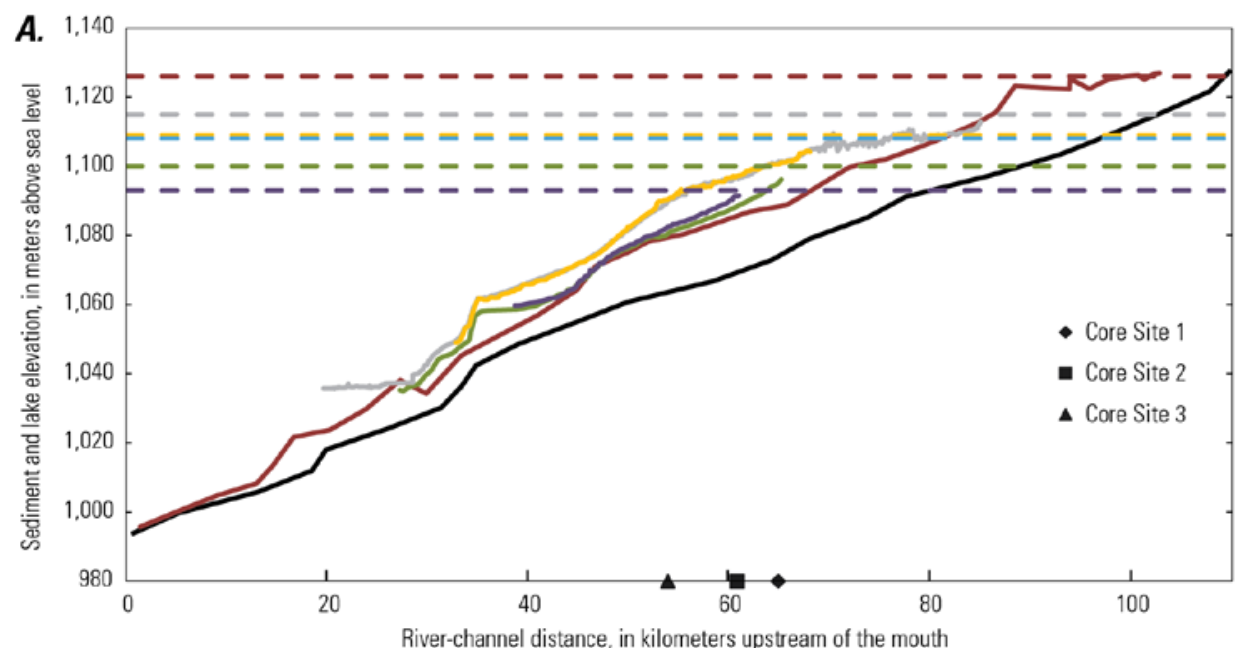

EXPLANATION
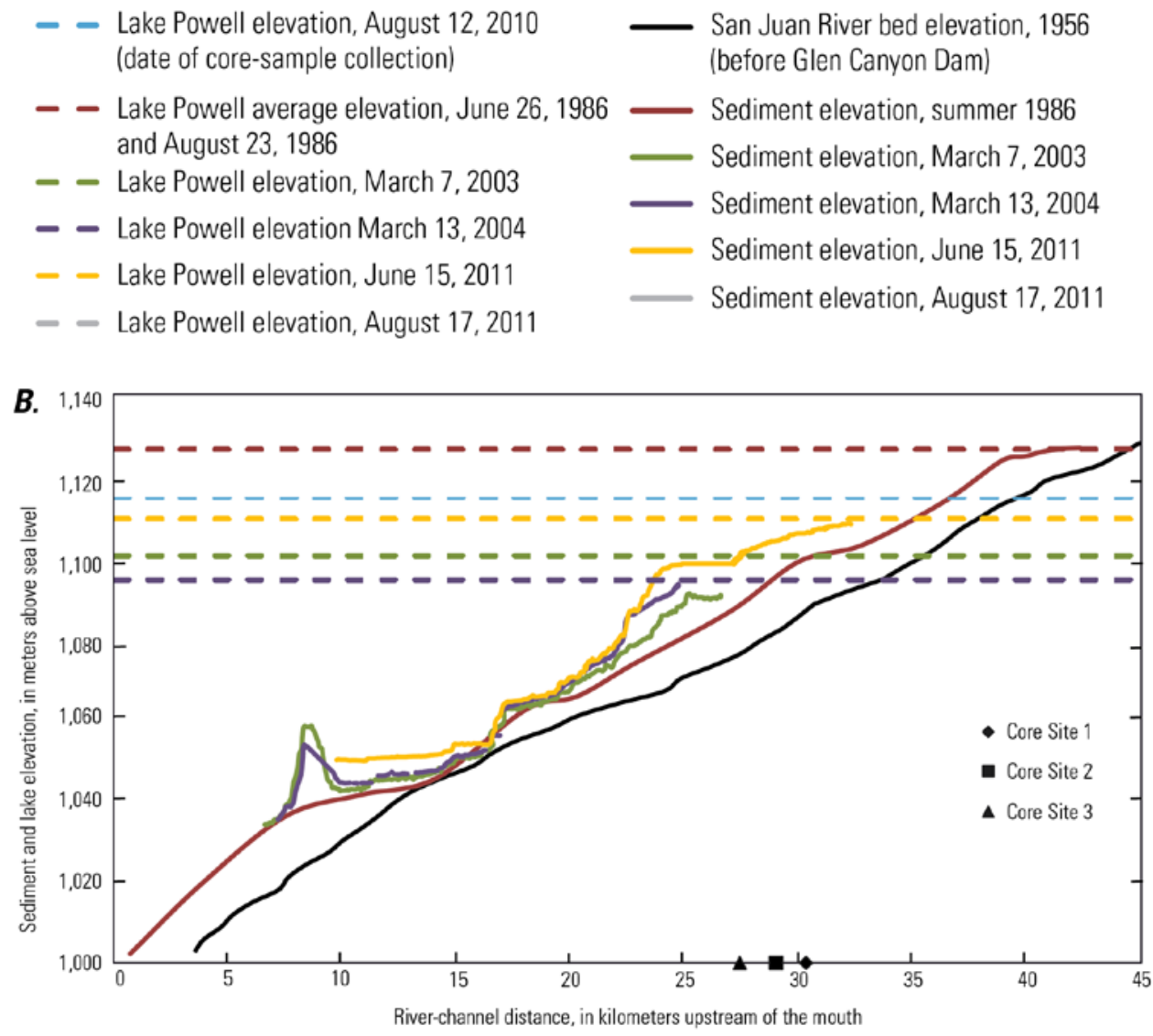

EXPLANATION

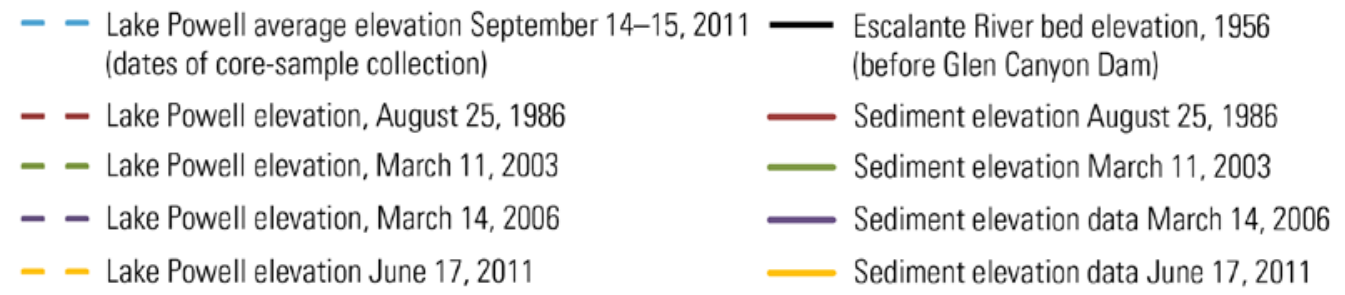


The purpose of this report is to present sediment and water chemistry analytical results from three sediment cores collected from the San Juan River delta in 2010 and three sediment cores and one replicate core collected from the Escalante River delta in 2011, and water-sample analytical results collected from water overlying the sediment-water interface above each of the cores collected from the San Juan River and Escalante River deltas (fig. 1). Sediment samples were analyzed for 55 major and trace elements, 55 low-level organochlorine pesticide and polychlorinated biphenyls, 61 polycyclic aromatic hydrocarbon compounds, gross alpha and gross beta radionuclides, and sediment-particle size. Water samples were analyzed for 57 major and trace elements. Site information, physical descriptions of the cores, summaries of analytical results, and complete analytical results for individual and composited samples are presented in spreadsheets in appendix A for the San Juan River delta and appendix B for the Escalante River delta.

\section{Methods}

This study uses the same coring equipment and follows the methodology used in a similar study examining contaminants in the Colorado River delta in Lake Powell by Hart and others (2005). Methods for this study are summarized below. For more detailed information on coring equipment and methods, and field-sample preservation, processing, analysis, and quality-control, refer to Hart and others (2005).

Sediment-coring locations for the San Juan River and Escalante River deltas were determined by reviewing recent channel-bottom surveys (measured using an echo sounder along the thalweg, or deepest part of the channel) conducted by the USGS-Grand Canyon Monitoring and Research Center (GCMRC) and results from a 1986 bathymetric survey conducted by the Bureau of Reclamation (fig. 2). Three coring locations were selected along the thalweg of each delta (fig. 1):

- Core 1 , the most upstream site, in an area where there was sufficient water depth (minimum of approximately $5 \mathrm{~m}$ ) to safely deploy the corer;

- Core 2, a middle site, in an area that was between the most upstream and downstream sites; and

- Core 3, the most downstream site, in an area where the water depth would be less than approximately $25 \mathrm{~m}$ (corer does not properly operate in greater depths).

One replicate core was collected at the site of the Escalante Core 3 sample. Selected delta sediment-accumulation profile surveys (channel-bottom surveys) from 1986 to 2011, corresponding lake elevations during the surveys, and coring locations for the San Juan River and Escalante River deltas are shown in figure 2. A Global Positioning System (GPS) was used to record the locations of each coring site.

Appendixes A1 and B1 show information on each of the coring locations, sediment-core sample dates, times and lengths, and USGS site numbers and names for each coresample location for the San Juan River and Escalante River deltas, respectively. Section 1, the uppermost section, of San Juan sediment Core 2 was damaged during collection and therefore, sediment from this section was unusable for analysis. The length of this damaged section was estimated to be between 174 and $226 \mathrm{~mm}$ long with an average length of $200 \mathrm{~mm}$, which is the estimate used to represent sediment thickness for section 1 in this report.

Once collected, the sediment cores were sectioned and frozen in the field and processed at the USGS-National Research Program (NRP) laboratory in Boulder, Colo. At the laboratory, the sections were thawed, physical descriptions of the strata within each section of the sediment cores were recorded (appendixes A2 and B2 for the San Juan River and Escalante River sediment cores, respectively), and the cores were sampled for analyses.

Two types of samples were collected from the sediment cores and are referred to as subsamples and composited samples (fig. 3). Subsamples are samples taken from various strata in the sediment core that may represent different sediment-chemistry properties and are analyzed individually. For composited samples each core was divided into two equal lengths and a longitudinal slice of sediment was removed from each length, one for the upper half and one for the lower half of the core. Each sediment slice was homogenized and analyzed.

Sediment subsamples and composited samples were analyzed for 55 major and trace elements at the USGSNRP laboratory. From the three San Juan cores, there were a total of 116 subsamples analyzed, including 15 laboratory replicates; also, 6 composited samples and 1 laboratory replicate composited sample were analyzed. From the three Escalante cores, a total of 75 subsamples were analyzed, including 14 laboratory replicates; also, 6 composited samples and 1 laboratory replicate composited sample were analyzed. In addition, 2 composited samples were analyzed from the Escalante Core 3 field replicate.

Composited samples also were analyzed for 55 low-level organochlorine pesticides and polychlorinated biphenyls (at the USGS National Water Quality Laboratory [NWQL]), 61 polycyclic aromatic hydrocarbon compounds (at the NWQL), gross alpha and gross beta radionuclides (at Eberline Services through the NWQL), and sediment-particle size (at the USGS Cascades Volcano Observatory Laboratory).

Water samples were collected from the sediment-water interface overlying each of Cores 1-3 collected from the San Juan River and Escalante River deltas. Each water sample was analyzed for 57 major and trace elements at the USGSNRP laboratory. 


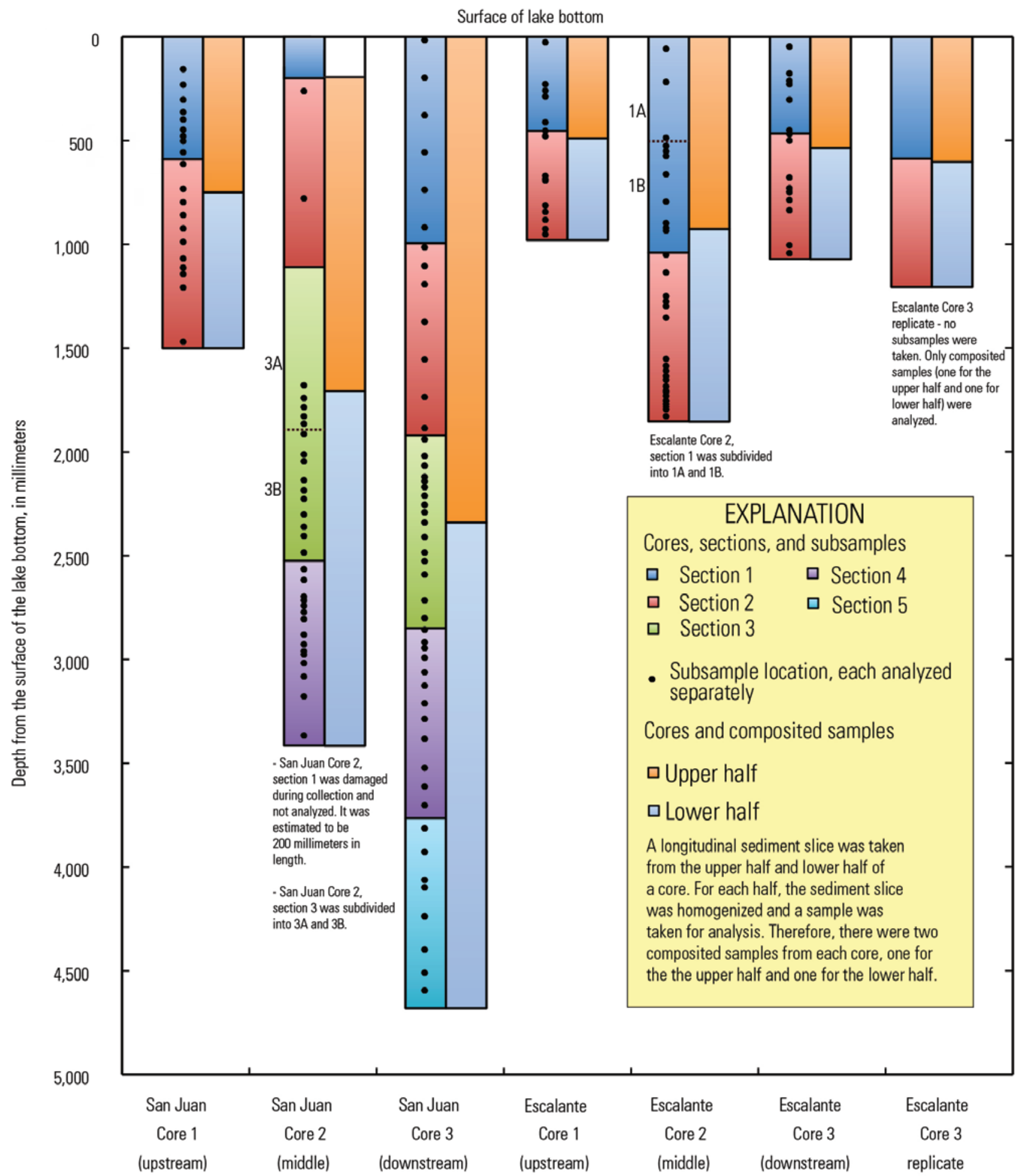

Figure 3. Logs showing cores, core sections and lengths, subsample locations, and composited samples collected from the San Juan River and Escalante River deltas, Lake Powell, Utah. 


\section{Summary of Core and Water Analyses}

Major and trace elements were detected at concentrations greater than reporting levels for most of the sediment subsamples and composited samples (appendixes A3-A5 for the San Juan and B3-B5 for the Escalante). For the San Juan, all elements were detected in each subsample except for rhenium, sulphur, selenium, and tellurium; and all elements were detected in each composited sample except for copper, rhenium, selenium, and tellurium. For the Escalante, all elements were detected in each subsample except for boron, bismuth, molybdenum, rhenium, sulphur, selenium, tin, tellurium, and zinc; and all elements were detected in each composited sample except for rhenium, selenium, and tellurium.

Low-level organochlorine pesticides and polychlorinated biphenyls were not detected in any of the sediment samples (appendixes A6-A7 for San Juan and B6-B7 for Escalante). Of the 61 PAH compounds analyzed, only 1 compound ( $\mathrm{p}$-Cresol) was detected at a concentration greater than the reporting level in only one sample - the San Juan Core 2, upper-half composited sample. Eighteen PAH compounds were detected in some San Juan samples and 5 PAH compounds were detected in some Escalante samples, but all concentrations were less than reporting levels (appendixes A8-A9 for San Juan and B8-B9 for Escalante).

Gross alpha and gross beta radioactivity concentrations were greater than reporting levels for all samples and ranged from 8 to $32 \mathrm{pCi} / \mathrm{g}$ for gross alpha radioactivity and from 17.1 to $34 \mathrm{pCi} / \mathrm{g}$ for gross beta radioactivity (appendixes A10-A11 for San Juan and B10-B11 for Escalante). Sediment particle-size analyses showed that the core samples primarily consisted of fine $(0.125 \mathrm{~mm})$ and very fine $(0.0625 \mathrm{~mm})$ sands, silts, and clays (appendixes A12 for San Juan and B12 for Escalante).

For the water samples, most of the 57 major and trace elements analyzed were detected at concentrations greater than reporting levels (appendixes A13-A14 for San Juan and B13-B14 for Escalante). For the San Juan, however, cobalt, cesium, europium, nickel, and thorium were not detected in any of the samples and cadmium, phosphorus, and tin were not detected in 67 percent of the samples. For the Escalante, cobalt, chromium, phosphorus, and tin were not detected in any of the samples and tellurium was not detected in 67 percent of the samples.

Results from all analyses are tabulated in appendix A for the San Juan River delta and appendix B for the Escalante River delta. The appendixes are Microsoft ${ }^{\circ}$ Excel 2010 Excel workbooks with an extension of .xlsx and are available for download from the report Web page at http://pubs.usgs.gov/ of/2014/1096/. Both appendixes have the same structure and include 15 worksheets. Although some results are available in the USGS National Water Information System-Web Interface (NWIS-Web) database, not all results are suitable for storage in NWIS-Web. As such, this report and attached appendixes will be used to archive these data.

\section{Consideration for Future Studies}

Lake Powell provides storage for water from three major rivers, the Colorado, the San Juan, and the Escalante Rivers, and more than 90 tributaries. The lake is used recreationally and provides habitat for many aquatic and terrestrial species. Glen Canyon NRA managers are concerned about the quality of water and deltaic sediment in the reservoir. This study expands a similar study done on the Colorado River delta in 2001. Additional studies could be done to further the existing work: (1) collect additional sediment cores from other large tributaries or areas of concern to Glen Canyon NRA to document the presence or absence of contaminants in sediment; (2) synthesize and document chemical analyses from all studies of the Colorado River, San Juan River, and Escalante River deltas; and (3) conduct additional chemical analyses on existing cores, such as age dating.

\section{Summary}

Lake Powell impounds three major rivers: the Colorado, San Juan, and Escalante. Sediment transported by these rivers form deltas in the inflow reaches to Lake Powell. Deltas are active areas of sediment deposition and erosion, and are potential sinks for contaminants. These contaminants may be released into the water as the deltas are reworked with changing lake levels, and may be harmful to humans and aquatic and terrestrial species. In 2010, the USGS began a sediment-core sampling and analysis program to assist Glen Canyon NRA managers, concerned about the quality of water and sediment in Lake Powell, document the presence or absence of contaminants in deltaic sediment from the two deltas that had not yet been studied, the San Juan River and Escalante River deltas.

Three sediment cores were collected from the San Juan River delta in the summer of 2010 and three sediment cores and one replicate core were collected from the Escalante River delta in the summer of 2011. Water samples also were collected from the sediment-water interface overlying each of the three cores from the San Juan River and Escalante River deltas. The cores were analyzed for 55 major and trace elements, 55 low-level organochlorine pesticides and polychlorinated biphenyls, $61 \mathrm{PAH}$ compounds, gross alpha and gross beta radionuclides, and sediment-particle size. The water samples were analyzed for 57 major and trace elements.

Most of the major and trace elements analyzed were detected at concentrations greater than reporting levels for the sediment-core subsamples and composited samples. Low-level organochlorine pesticides and polychlorinated biphenyls were not detected in any of the samples. One PAH compound, p-Cresol, was detected at a concentration greater than the reporting level for one sample (San Juan Core 2, upper-half composited sample). Gross-alpha and gross-beta radionuclide concentrations were greater than reporting 
levels for all samples. The cores primarily consisted of fine sand, very fine sand, silts, and clays. Most of the major and trace elements analyzed were detected at concentrations greater than reporting levels for the water samples. Cobalt, cesium, europium, nickel, and thorium were not detected in water samples from the San Juan, and cobalt, chromium, phosphorus, and tin were not detected in water samples from the Escalante.

\section{References Cited}

Ferrari, R.L., 1988, 1986 Lake Powell Survey: Denver, Colorado, U.S. Bureau of Reclamation Technical Report REC-ERC-88-6, 67 p.

Hart, R.J., Taylor, H.E., Antweiler, R.C., Fisk, G.G., Anderson, G.M., Roth, D.A., Flynn, M.E., Peart, D.B., Truini, Margot, and Barber, L.B., 2004, Physical and chemical characteristics of Knowles, Forgotten, and Moqui Canyons, and effects of recreational use on water quality, Lake Powell, Arizona and Utah, U.S. Geological Survey Open-File Report 20045120,43 p.

Hart, R.J., Taylor, H.E., Antweiler, R.C., Graham, D.D., Fisk, G.G., Riggins, S.G., and Flynn, M.E., 2005, Sediment chemistry of the Colorado River delta of Lake Powell, Utah, 2001: U.S. Geological Survey Open-File Report 2005-1178, $33 \mathrm{p}$.

Potter, L.D., and Drake, C.L., 1989, Lake Powell: Virgin flow to dynamo: Albuquerque, University of New Mexico Press, $311 \mathrm{p}$.

Pratson, L., Hughes-Clarke, J., Anderson, M., Gerber, T., Twichell, D., Ferrari, R., Nittrouer, C., Beaudoin, J., Granet, J., and Crockett, J., 2008, Timing and patterns of basin infilling as documented in Lake Powell during a drought: Geology, v. 36, no. 11, p. 843-846.

Vernieu, W.S., 1997, Effects of reservoir drawdown on resuspension of deltaic sediments in Lake Powell: Lake and Reservoir Management, v. 13, no. 1, p. 67-78.

\section{Appendixes}

Results from all analyses are tabulated in appendix A for the San Juan River delta and appendix B for the Escalante River delta. The appendixes are Microsoft $^{\mathscr{C}}$ Excel 2010 Excel workbooks with an extension of .xlsx and are available for download from the report Web page at http://pubs.usgs.gov/ of/2014/1096/.

Appendix A. Sediment Core Information and Sediment-Chemistry and Water-Sample Results for the San Juan River delta, Lake Powell, Utah, 2010.

\section{Appendix B. Sediment Core Information and Sediment-Chemistry and Water-Sample Results for the Escalante River delta, Lake Powell, Utah, 2011.}



Menlo Park Publishing Service Center, California

Manuscript approved for publication May 9, 2014

Edited by John Buursma

Design and layout by Cory Hurd 
